JURNAL PENDIDIKAN, p-ISSN 2715-095X, e-ISSN 2686-5041

Volume 30, No.2, Juli 2021 (245-260)

Online: http://journal.univetbantara.ac.id/index.php/jp

\title{
Penerapan Metode Group Investigation untuk Meningkatkan Motivasi dan Kemampuan Menganalisis Kebahasaan Teks Laporan Hasil Observasi Peserta Didik Kelas X IPS 1 SMA Negeri 1 Gemolong Tahun Pelajaran 2019/2020
}

\section{Giyono}

SMA Negeri 1 Gemolong, Kabupaten Sragen, E-mail: giyono1603@gmail.com

Received: March 3, 2021

Accepted: April 24, 2021

Online Published: Juni 26, 2021

\begin{abstract}
Abstrak: Tujuan penelitian ini adalah untuk mendeskripsikan, menjelaskan pelaksanaan model pembelajaran Group Investigation (GI) dan dengan penerapan model pembelajaran tersebut untuk meningkatkan motivasi dan kemampuan menganalisis kebahasaan teks laporan hasil observasi pada peserta didik kelas X IPS 1 SMA Negeri 1 Gemolong. Penelitian ini adalah penelitian tindakan kelas yang dilaksanakan dalam 2 siklus dengan dua pertemuan dan tiap pertemuan terdiri dari perencanaan, tindakan, pengamatan, dan refleksi. Subjek penelitian adalah peserta didik kelas X IPS 1 SMA Negeri 1 Gemolong pada semester 1 tahun elajaran 2019/2020. Sumber ata diperoleh dari guru, peserta didik, tempat, dan peristiwa berlangsungnya aktivitas pembelajaran dan dokumentasi.. Teknik dan alat pengumpulan data menggunakan observasi. Validitas data menggunakan trianggulasi sumber data. Analisis data menggunakan analisis kualitatif. Hasil penelitian menunjukkan bahwa sebelum tindakan penelitian kelas, ratarata- kemampuan peserta didik dalam menganalisis kebahasaan teks laporan hasil observasi mendapat skor 68, setelah diadakan tes siklus I mendapat skor rata-rata 77,81 dan setelah siklus II rata-rata skor 85,03.Sementara keaktifan dalam embelajaran teks laporan hasil observasi juga meningkat setiap pertemuan pada siklusnya, siklus I rata-rata 69,4 , siklus II rata-rata 85,8 . Berdasarkan hasil observasi kinerja guru juga mengalami eningkatan sehingga hal tersebut memengaruhi kemampuan menganalisis kebahasaan teks laporan hasil observasi pada peserta didik kelas X IPS 1 SMA Negeri 1 Gemolon. Bedasarkan hasil penelitian di atas, dapat disimpulkan bahwa penerapan pendekatan kooperatif tipe Group Inestigation dapat meningkatkan motivasi menganalisis kebahasaan teks laporan hasil observasi dan meningkatkan kemampuan menganalisis kebahasaan teks laporan hasil observasi Peserta Didik Kelas X IPS 1 Semester 1 SMA Negeri 1 Gemolong Tahun Pelajaran 2019/2020
\end{abstract}

Kata-kata Kunci: Metode group investigation, meningkatan motivasi dan kemampuan, menganalisis.

\section{The Implementation of Group Investigation Method Increased Motivation and Ability to Analyze Observation Report Text through in Learner class $X$ IPS 1 SMA Negeri 1 Gemolong in the Academic Year of 2019/2020}

\section{Giyono}

SMA Negeri 1 Gemolong, Sragen Regency,E-mail: giyono1603@gmail.com

\begin{abstract}
The purpose of this research is to describe, explain implementation Group Investigation learning model and with that learning model application to increase motivation and observation report text analyze ability for the student of XIPS 1 SMA Negeri 1 Gemolong. The research is class action research which execute in 2 cycles with two meeting and every
\end{abstract}


meeting consist of planning, action, observation, and reflection. This subject of research is the student of X IPS 1 SMA Negeri 1 Gemolong at semester 1 period 2019/2020. Data source is abtained by teacher, student, place, and learning activity and documentation event be helding. Technique and data s gathering devide use observation. The data s validity user data source triangulation. Data s analysis uses qualitative analysis. The result of research indicates that before the class research action, the student's ability to analyzing observation report text to reach score 68, after cycle I is held, getting average score 77,81 and after cycle II average get score 85,03, white being active in observation report text learning also increasing in every meeting at the cycle, averaging cycle I is 69,4, averaging cycle II is 85,8. Based on the result of teacher's performance observation also increasing until that influence the student's analyzing observation report text ability, especially the student's of X IPS 1 SMA Negeri 1 Gemolong. Based on the result of research above, we can conclude that application of cooperative type Group Investigation approach can increasing motivation to analyze observation report text and increasing ability the student's of X IPS Semester 1 SMA Negeri 1 Gemolong, in period 2019/2020 to analyze observation report text.

Keywords: Group Investigation's methods motivation and ability increase, analyzing

\section{Pendahuluan}

Pembelajaran bahasa Indonesia dikhususkan pada peningkatan kemampuan peserta didik untuk berkomunikasi dengan baik dan benar, baik lisan maupun tulisan, serta menumbuhkan apresiasi terhadap hasil karya kesastraan manusia Indonesia. Pembelajaran bahasa perlu dikembangkan menjadi pembelajaran keterampilan berbahasa bukan hanya pembelajaran tentang tata bahasa. Aktivitas pembelajaran di SMA Negeri 1 Gemolong Kabupaten Sragen saat ini masih kurang mendorong peserta didik untuk aktif dan berpikir kritis, terutama pembelajaran pada aspek membaca. Pada aspek ini belum tampak hasil seperti apa yang diharapkan. Pembelajaran membaca kurang mendapat perhatian sewajarnya dan tidak ditangani sebagaimana mestinya. Guru dan siswa biasanya lebih menfokuskan kegiatan pembelajaran pada materi-materi teoritis yang mengarah pada keberhasilan siswa dalam pencapaian nilai ujian. Guru sekadar mentransfer materi dan siswa jarang dirangsang untuk menghadapi permasalahan-permasalahan. Seharusnya dalam pembelajaran peserta didik harus terlibat secara aktif dengan membangun pengetahuan sendiri. Guru harus memberikan dukungan dan kesempatan kepada peserta didik untuk mengembangkan ide-ide dalam belajar. Dengan demikian dibutuhkan adanya penerapan teknik atau metode yang tepat dalam pembelajaran. Hal itu akan mempermudah peserta didik menyerap materi ajar karena adanya rasa nyaman dalam melaksanakan pembelajaran.

Sesuai sistem penilaian Permendikbud nomor 24 tahun 2016, data arsip daftar nilai yang ada pada peneliti ulangan formatif di kelas X IPS 1 SMA Negeri 1 Gemolong Kabupaten Sragen, khususnya untuk materi "Menganalisis Kebahasaan Teks Laporan Hasil Observasi", memiliki rata-rata yang paling rendah dibandingkan dengan kelas lain. Nilai terendah yang diperoleh siswa adalah 61 dan nilai tertinggi diperoleh siswa adalah 86. Nilai rata-rata mencapai 68 dan rata-rata ketuntasan klasikal hanya mencapai $65 \%$ yang mendapat nilai lebih dari atau sama dengan 75 (KKM), sedangkan batas tuntas harus mencapai standar kriteria ketuntasan minimun yaitu nilai rata-rata lebih dari $75 \%$ dan ketuntasan klasikal minimun mencapai $85 \%$ dari jumlah peserta didik dalam kelas yang diteliti. Disamping itu untuk nilai kompetensi keterampilan adalah nilai terendah 43, nilai tertinggi 79 , rata-rata klasikal 60, dan ketuntasan klasikal hanya 65\%. Ketentuan nilai secara individu minimum adalah 75 (KKM). Rendahnya hasil belajar bahasa 
Indonesia khususnya materi "Menganalisis Kebahasaan Teks Laporan Hasil Observasi" disebabkan kurang efektifnya proses pembelajaran di kelas. Faktor negatif yang lain adalah rendahnya aktivitas belajar peserta didik. Indikasi adanya kurang keaktifan peserta didik yaitu peserta didik takut bertanya, penyajian materi kurang menarik. Hal tersebut dikarenakan bahan hanya buku pegangan, kurangnya fasilitas kelas atau LCD yang sudah rusak, dan keterbatasan kemampuan guru dalam menerapkan variasi metode pembelajaran. Untuk mengetahui kemampuan dalam menganalisis suatu teks sehingga ada peningkatan kualitas proses belajar bahasa Indonesia maka diperlukan peningkatan kualitas para pendidik. Sebenarnya bukan hanya penyusunan kembali kurikulum dalam bentuk RPP yang lebih sempurna, melainkan pembenahan metode yang sesuai dengan memperhatikan mata pelajaran, fasilitas, dan kondisi peserta didik sebagai subyek penelitian yakni motivasi belajar yang dimiliki, minat, ketekunan, dan karakteristik. Sehingga semakin baik metode yang digunakan maka makin efektif pula dalam pencapaian tujuan pembelajaran yang dimaksud.

Berdasar latar belakang masalah di atas maka perlu adanya pembaharuan dalam pelaksanaan pembelajaran terutama penggunaan metode pembelajaran. Metode pembelajaran merupakan cara yang dipergunakan oleh guru dalam mengadakan hubungan dengan peserta didik selama berlangsungnya pembelajaran. Dan akhirnya pembelajaran akan mudah dipahami oleh peserta didik. Penggunaan beberapa metode dalam pembelajaran harus sesuai dengan materi yang ada. Adapun materi yang dibahas dalam penelitian ini adalah "Menganalisis Kebahasaan Teks Laporan Hasil Observasi". Agar materi mudah dipahami oleh peserta didik maka perlu penyajian dan pembahasan dengan menggunakan metode yang tepat yaitu metode Group Investigation. Dengan metode Group Investigation maka akan memberi peserta didik waktu yang lebih banyak berpikir dan saling membantu satu sama lain sehingga peserta didik lebih aktif dalam pembelajaran. Dengan harapan pembelajaran dapat berpengaruh positif terhadap hasil belajar yang dicapai oleh peserta didik. Perumusan masalah di dalam penelitian ini adalah sejauh mana peserta didik aktif saat mengikuti proses pembelajaran, apakah penerapan metode Group Investigation dapat meningkatkan motivasi menganalisis kebahasaan teks laporan hasil observasi pada peserta didik kelas X IPS 1 Gemolong, dan apakah penerapan metode Group Investigation dapat meningkatkan kemampuan menganalisis kebahasaan teks laporan hasil observasi pada peserta didik kelas X IPS 1 SMA Negeri 1 Gemolong. Pada dasarnya penelitian ini diharapkan dapat berhasil dengan baik, yaitu dapat mencapai tujuan penelitian secara maksimal, menghasilkan laporan yang sistematis. Adapun manfaat yang diambil dari penelitan ini bagi peserta didik dapat meningkatkan keaktifan / motivasi peserta didik yaitu mengajukan pertanyaan, mengambil giliran, berbagai tugas, dan mendengarkan secara aktif, meningkatkan kemampuan peserta didik dalam menganalisis suatu teks. Sedangkan bagi guru memberikan alternatif metode pembelajaran yang lain bagi guru bahasa Indonesia untuk meningkatkan kemampuannya, serta bagi sekolah dapat meningkatkan kualitas sekolah melalui peningkatan motivasi dan kemampuan peserta didik dan kinerja guru. Sudah banyak sekali para ahli psikologi pendidikan dan psikologi perkembangan yang membahas tentang motivasi dalam pembelajaran. Sedemikian banyaknya pembahasan tentang motivasi dalam pembelajaran itu telah menghasilkan definisi motivasi yang banyak pula. Namun demikian pada intinya, motivasi dapat diartikan sebagai (1) Dorongan yang timbul pada diri seseorang, secara disadari atau tidak disadari, untuk melakukan suatu tindakan dengan tujuan tertentu. (2) Usaha-usaha yang dapat menyebabkan seseorang atau kelompok orang tertentu tergerak 
melakukan sesuatu karena ingin mencapai tujuan yang ingin dicapai (Mohammad Asrori, 2007). Pendapat lain bahwa motivasi berasal dari kata "motif" yang diartikan sebagai daya upaya yang mendorong seseorang untuk melakukan sesuatu. Menurut Sardiman (2006:73) motif merupakan daya penggerak dari dalam untuk melakukan kegaiatan untuk mencapai tujuan. Mulyasa (dalam Giyono, 2019: 3) mengatakan bahwa motivasi adalah tenaga pendorong atau penarik yang menyebabkan adanya tingkah laku kearah suatu tujuan tertentu. Peserta didik akan bersungguh-sungguh karena memiliki motivasi yang tinggi. Seorang siswa akan belajar bila ada faktor pendorongnya yang disebut motivasi. Dimyati dan Mudjiono (2002:80) mengutip pendapat Koeswara mengatakan bahwa siswa belajar karena didorong kekuatan mental, kekuatan mental itu berupa keinginan dan perhatian, kemauan, cita-cita di dalam diri seorang terkadang adanya keinginan yang mengaktifkan, menggerakkan, menyalurkan dan mengarahkan sikap dan perilaku individu dalam belajar. Menurut Sanjaya (dalam Joko Budi Marsono, 2020:1) bahwa belajar adalah proses mental yang terjadi dalam diri seseorang, sehingga menyebabkan mnculnya perubahan tingkah laku. Jadi dapat disimpulkan bahwa motivasi belajar adalah keseluruhan daya penggerak di dalam diri peserta didik yang menimbulkan kegiatan belajar menjamin kelangsungan dan memberikan arah pada kegitan belajar sehingga tujuan yang dikehendaki dapat tercapai. Dalam motivasi belajar dorongan merupakan kekuatan mental untuk melakukan kegiatan dalam rangka pemenuhan harapan dan dorongan dalam hal ini adalah pencapaian tujuan. Kemampuan atau kompetensi adalah suatu pengetahuan, keterampilan, dan nilai-nilai dasar yang direfleksikan dalam kebiasaan berpikir dan bertindak ( Depdikbud, $2004: 5$ ). Kemampuan atau kompetensi adalah suatu ketrampilan untuk mengeluarkan sumbr dya bakat atau internal dalam diri seseorang yang dapat memberikan manfaat bagi diri sendiri maupun orang lain. Pada hakikatnya setiap manusia mempunyai kemampuan yang dibawa sejak lahir. Kemampuan terus berkembang dan berproses sesuai dengan bertambahnya usia seseorang. Kemampuan atau kompetensi seseorang tidak akan berkembang dengan baik kalau tidak disertai demgam usaha yang terus menerus. Kemampuan seseorang dapat berkembang dengan baik jika disertai dengan usaha yang sungguh-sungguh. Senada dengan hal tersebut, Mulyasa (2007:215) menegaskan bahwa kompetensi yang harus dimiliki peserta didik perlu dinyatakan sedemikian rupa agar dapat dinilai, sebagai wujud hasil belajar yang mengacu pada pengalaman langsung. Benny A Pribadi (dalam Purnyomo, 2011:5) bahwa kompetensi adalah pengetahuan, keterampilan, sikap yang memungkinkan seseorang dapat melakukan aktivitas secara efektif dalam melaksanakan tugas dan fungsi pekerjaan sesuai dengan standar yang telah ditentukan. Kemampuan belajar digunakan untuk menyebutkan kemampuan individu yang berfungsi dalam lingkungan yang membutuhkan suatu usaha yang bersifat kognitif. Setiap kompetensi harus merupakan perpaduan dari pengetahuan, keterampilan, nilai, dan sikap yang direfleksikan dalam kebiasaan berpikir dan bertindak (Mulyasa, 2007: 215). Menurut Martinis Yamin (2007: 1) kompetensi adalah kemampuan yang dapat dilakukan siswa mencakup tiga aspek, yaitu pengetahuan, keterampilan, dan sikap Kemampuan menganalisis berarti kemampuan seseorng yang diwujudkan dalam penguasaan ketrampilan untuk dapat menganalisisnya. Kemampuan menganalisis merupakan kemampuan individu yang menentukan bagian-bagian dari suatu masalah dan menunjukkan hubungan antar-bagian tersebut, melihat penyebab-penyebab dari suatu peristiwa atau memberi argument-argumen yang menyokong suatu pernyataan. Kemampuan menganalisis merupakan salah satu kemampuan kognitif tingkat tinggi yang penting untuk dikuasai peserta didik dalam pembelajaran. Metode Group Investigation 
seringkali disebut metode pembelajaran kooperatif yang paling kompleks. Hal ini disebabkan oleh metode ini memadukan beberapa landasan pemikiran, yaitu berdasarkan pandangan konstruktivistik, democratic teaching, dan kelompok belajar kooperatif. Berdasarkan pandangan konstruktivistik, proses pembelajaran dengan model group investigation memberikan kesempatan seluas-luasnya kepada siswa untuk terlibat secara langsung dan aktif dalam proses pempelajaran mulai dari prencanaan sampai mempelajar suatu topik melalui investigasi. Menurut Joyce (dalam Wiwik Hariyati, 2017: 2) menyatakan bahwa model pembelajaran mengarahkan kita ke dalam mendesain pembelajaran untuk membantu peserta didik sedemikian rupa sehingga tujuan pembelajaran tercapai. Democratic teaching adalah proses pembelajaran yang dilandasi oleh nilai-nilai demokrasi, yaitu penghargaan terhadap kemampuan, menjunjung keadilan, menerapkan peramaan kesempatan, dan memperlihatkan keberagaman peserta didik. Eggen \& Kauchak (dalam Maimunah, 2005: 21) mengemukakan Group Investigation adalah strategi belajar kooperatif yang menempatkan siswa ke dalam kelompok untuk melakukan investigasi terhadap suatu topik. Dalam pernyataan tersebut dapat disimpulkan bahwa metode GI mempunyai focus utama untuk melakukan investigasi terhadap suatu topik atau objek khusus. Pandangan peneliti W Gulo (2002: 127-131) menekankan peran penting guru di dalam pembelajaran yaitu sebagai pendorong timbulnya factor-faktor positif dan mengurangi factor-faktor negatif. Isjoni (dalam Suyoto, 2020: 1) menyatakan bahwa dalam pembelajaran kooperatif, belajar dikatakan belum selesai jika salah satu teman alam kelompok belum menguasai bahan pembelajaran. Menurut Suherman dkk. (dalam Sjafruddin Djoko Hidajat Nur, 2011:5) pembelajaran kooperatif mencakup suatu kelompok kecil siswa yang bekerja sebagai sebuah tim untuk menyelesaikan suatu masalah, mengerjakan tugas atau mengerjakan sesuatu untuk mencapai tujuan bersama. Kesimpulannya bahwa group investigation adalah kelompok kecil untuk menuntun dan mendorong peserta didik dalam keterlibatan belajar. Metode ini menuntut peserta didik untuk memilik kemampuan yang baik dalam berkomunikasi maupun dalam keterampiln proses kelompok (group process skills). Hasil akhir dari kelompok adalah sumbangan ide dari tiap anggota serta pembelajaran kelompok yang notabene lebih mengasah kemampuan intelektual peserta didik dibandigkan belajar secara individual. Metode Group Investigation paling sedikit memiliki tiga tujuan yang saling terkait yaitu Group Investigasi membantu siswa untuk melakukan investigasi terhadap suatu topik secara sistematis dan analitik. Hal ini mempunyai implikasi yang positif terhadap pengembangan keterampilan penemuan dan membantu mencapai tujuan. Yang kedua pemahaman secara mendalam terhadap suatu topic yang dilakukan melalui investigasi Berikutnya Group Investigasi melatih siswa untuk bekerja secara kooperatif dalam memecahkan suatu masalah. Dengan adanya kegiatan tersebut, siswa dibekali keterampilan hidup yang berharga dalam kehidupan bermasyarakat. Jadi guru menerapkan model pembelajaran GI dapat mencapai tiga hal, yaitu dapat belajar dengan penemuan, belajar isi, dan belajar untuk bekerja secara kooperatif. Sharan (dalam Supandi, 2005: 6) mengemukakan langkah-langkah pembelajaran pada model GI sebagai berikut: Guru membagi kelas menjadi beberapa kelompok yang heterogen, guru menjelaskan maksud pemelajaran dan tugas kelompok yang harus dikerjakan, guru memanggil ketua-ketua kelompok untuk mengambil materi tugas secara kooperatif dalam kelompoknya, masing-masing kelompok membahas materi tugas secara kooperatif dalam kelompoknya, setelah selesai, masingmasing kelompok yang diwakili ketua kelompok atau salah satu anggotanya menyampaikan hasil pembehasannya, guru memberikan tanggapan terhadap hasil 
pembahasannya, guru memberikan penjelasan singkat (Klarifikasi) bila terjadi kesalahan konsep dan memberikan kesimpulan, dan evaluasi (Suwarto, 2017). Kerangka berpikir dalam penelitian ini dapat diterangkan sebagai berikut: kondisi awal tindakan dilaksanakan, diperoleh gambaran (yang dilakukan pada kegiatan prasurvei dengan observasi, wawancara, dan angket) bahwa dalam pembelajaran menganalisis teks anekdot yang berlangsung di SMA Negeri 1 Gemolong, (1) nilai kemampuan menganalisis teks negosiasi masih rendah, (2) guru menggunakan metode ceramah dan penugasan dalam menyampaikan materi sehingga peserta didik kurang dilibatkan secara aktif dalam pembelajaran, (3) peserta didik kurang tertarik atau kurang senang dengan materi pelajaran teks negosiasi karena mereka menganggap kurang bermanfaat dalam kehidupan nyata dan menganggap teks negosiasi tersebut hanya teks asal-asalan. Dari kondisi ini, peneliti mencobamenawarkan pembelajaran kooperatif metode Group Investigation untuk pembelajaran menganalisis teks negosiasi. Pada metode pembelajaran ini para peserta didik bekerja melalui enam tahap. Tahap pertama mengidentifikasi topik, tahap kedua merencanakan kerja sama, tahap ketiga implementasi, tahap empat analisis sintesis, tahap lima penyajian hasil akhir, dan tahap enam evaluasi. Untuk lebih jelasnya tentang kerangka berpikir pada penelitian ini dapat dilihat pada gambar berikut.

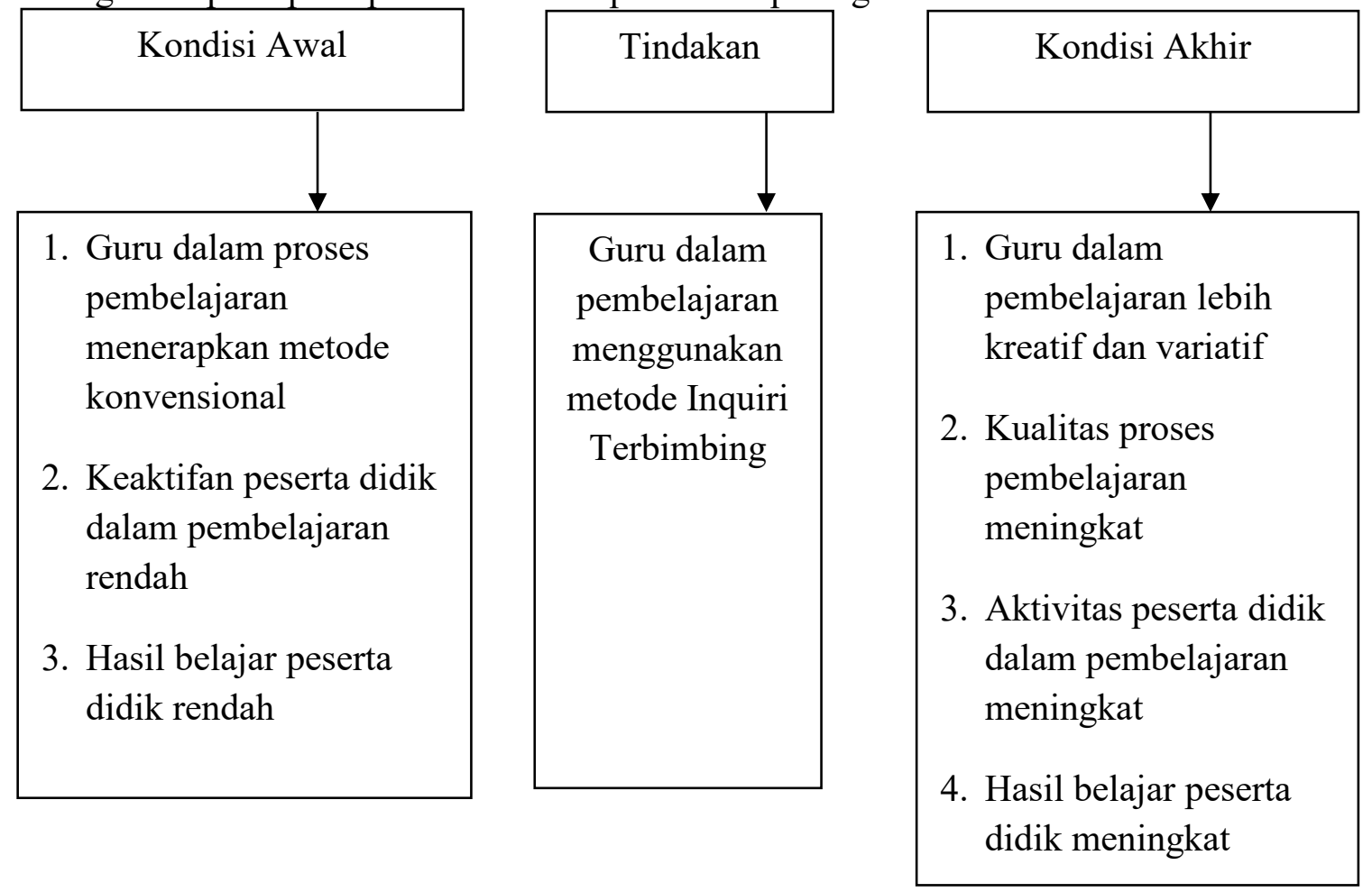

Gambar 1. Kerangka Berpikir

Berdasarkan kajian teoritis dan kerangka berpikir, maka hipotesis penelitan ini dapat dirumuskan sebagai berikut: 1) Penerapan metode Group Investigation dapat meningkatkan keaktifan peserta didik selama pembelajaran, 2) Penerapan metode Group Investigation dapat meningkatkan motivasi peserta didik selama pembelajaran, 3) Penerapan metode Group Investigation dapat meningkatkan kemampuan peserta didik selama pembelajaran. 
Penelitian dilakukan di SMA Negeri 1 Gemolong, Sragen yang beralamat di Jalan Citosancakan, Gemolong, Sragen. Sekolah ini mempunyai 28 kelas. Tindakan penelitian dilakukan dikelas X IPS 1 karena pada keas ini terdapat permasalahan yang perlu segera diatasi untuk memperbaiki proses dan hasil belaja bahasa Indonesia khususnya pada kompetensi dasar menganalisis teks laporan hasil observasi dan kebetulan penulis sebagai guru di kelas tersebut. Subyek penelitian ini adalah peerta didik kelas X IPS 1 SMA Negeri 1 Gemolong tahun pelajaran 2019-2020. Peserta didik tersebut berjumlah 36 orang, dengan laki-laki sebanyak 14 orang dan perempuan sebanyak 22 orang. Sedangkan obyek penelitiannya adalah motivasi dan kemampuan prestasi belajar. Pembelajaran menganalisis kebahasaan teks laporan hasil observasi dengan menggunakan metode Group Investigation yang akan dilaksanakan berdasarkan Standar Kompetensi dan Kompetesi Dasar sesuai dengan kurikulum2013 kelas X semester 1. Desain penelitian ini adalah suatu rangkaian tahap-tahap penelitian dari awal sampai akhir. Pada model ini dalam setiap siklusnya menempuh menempuh empat tahapan, antara lain: (1) perencanaan, (2) pelaksanaan, (3) observasi, (4) analisis dan refleksi, menurut Suharsini Arikunto ( dalam Triman 2017: 221). Keempat kegiatan tersebut saling terkait dan secara urut membentuk sebuah siklus. Teknik pengumpulan data yang digunakan penulis adalah tes yang berbentuk obyektif maupun uraian digunakan untuk mengukur keberhasilan peserta didik dalam belajar. Penulis menggunakan jenis tes evaluasi yang berupa soal. Observasi untuk mengukur keberhasilan keaktifan guru dan mitra kolaborasi melakukan observasi dengan lembar observasi kemudian mencatat peristiwa dalam pembelajaran. Teknik ini digunakan untuk mengamati perkembangan yang dilakukan peserta didik dan guru sejak sebelum diberikan tindakan, pada saat pelaksanaan tindakan, sampai akhir tindakan. Kegiatan yang diamati meliputi pembelajaran menganalisis kebahasaan teks laporan hasil observasi yang dilakukan oleh guru sesuai RPP yang dibuat oleh peneliti dan guru. Peran peneliti dalam kegiatan ini adalah sebagai partisipan pasif. Hasil observasi didiskusikan dengan guru yang bersangkutan, kemudian dianalisis untuk mengetahui berbagai kelemahan yang ada dan untuk mencarisolusi terhadap kelmahan tersebut. Hasil diskusi berupa solusi untuk berbagai kelemahan tersebut kemudian dilaksanakan dalam silus berikutnya. .Berikutnya adanya dokumentasi, yang berupa hasil tes peserta didik dianalisis secara kuantitatif. Selanjutnya ditentukan nilai pengetahuan dengan peringkat tinggi, rendah, rerata, dan ketuntasan. Untuk nilai keterampilan juga meliputi nilai tinggi, rendah, dan rerata.

Validitas data yang digunakan dalam penelitian ini adalah teknik trianggulasi sumber data dan teknik trianggulasi metode. Trianggulasi sumber data yaitu menggali data yang sejenis dari berbagai sumber data yang berbeda. Peneliti menggali dari informan yang berbeda-beda posisinya dengan wawancara sehingga informasi dan informan satu dapat dibandingkan dengan informan lain. Selain itu, penelii juga menggali data dari arsip atau dokumen, dan hasil observasi terhadap aktivitas pembelajaran yang dilakukan. Trianggulasi metode adalah menggali data yang sama dengan menggunakan metode pengumpulan data yang berbeda. Hal ini dilakukan untuk menggali data tentang pelaksanan pembelajaran menganalisis kebahasaan teks laporan hasil observasi yang diperoleh dari metode wawancara dengan informan guru dan peserta didik, dari metode analisis dokumen berupa persiapan tertulis yang sudah dibuat oleh guru dan dari observasi pelaksanaan pembelajaran menganalisis kebahasaan teks laporan hasil observasi yang berlangsung. Tekni analisis data yang digunakan adalah dengan menganalisis secara deskriptif dan kualitatif. Menurut Suharsini Arikunto, dkk. (2008: 131-132), analisis deskriptif adalah menganalisis data kuantitatif yang berupa nilai hasil belajar siswa. Teknik analisis deskriptif dapat digunakan 
untuk mengolah data yang berkaitan dengan menjumlah, merata-rata, mencari persentasi, dan menyajikan data secara menarik, mudah dibaca dan diikuti alur berpikirnya (tabel, grafik, chart). Teknik ini digunakan untuk membandingkan nilai tes antarsiklus. Peneliti membandingkan hasil sebelum dengan hasil pada akhir setiap siklus. Teknik analisis data berikutnya adalah secara kualitatif. Data kualitatif adalah data yang berupa informasi berbentuk kalimat yang nenberikan gambaran tentang tingkat pemahaman (kognitif) siswa, pandangan atau sikap siswa terhadap metode belajar yang baru (afektif), dan aktivitas siswa dalam mengikuti pelajaran. Untuk data kualitatif yang berupa hasil wawancara baik wawancara peneliti dengan guru maupun peneliti dengan siswa, hasil pengamatan, dan angket, peneliti biasanya melakukan proses koding untuk mengorganisasi data. Tahapan proses koding adalah membuat matrik dari data yang terkumpul, memberi kode untuk masing-masing sel, membaca data secara menyeluruh dan menentukan sesuai tema, mengelompokkan masing-masing pernyataan ke dalam kotak-kotak sel, mengaitkan antara sel sehingga mengandung makna, membat interpretasi dari data yang terdapat dalam sel, dan mendeskripsikan secara jelas data dalam sel atau matrik sehingga menjadi suatu kesimpulan( Suharsimi Arikunto, dkk, 2008:132. Hasil analisis deskriptif maupun analisis kualitatif dijadikan dasar dalam menyusun perencanaan tindakan untuk tahap berikutnya sesuai dengan siklus yang ada. Analisis data dilakukan bersamaan dan atau setelah pengumpulan data.

Indikator keberhasilan dalam Penelitian Tindakan Kelas (PTK) yang dilakukan pada siswa kelas X IPS 1 SMA Negeri 1 Gemolong denga ukuran keberhasilan penelitian yang ingin dicapai meningkatnya motivasi dan kemampuan peserta didik dalam menganalisis kebahasaan teks laporan hasil observasi dengan menggunakan metode Group Investigation. Indikator yang digunakan untuk mengetahui peningkatan tersebut adalah keaktifan peserta didik meningkat dengan tuntas belajar secara klasikal ( $\geq 85 \%$ ), nilai pengetahuan pada akhir siklus minimal mencapai KKM ( $\geq 75 \%$ ), dan nilai keterampilan pada akhir siklus minimal mencapai KKM.

\section{Hasil Penelitian}

Kondisi awal untuk pembelajaran menganalisis kebahasaan teks laporan hasil observasi dan tes kemampuan awal peserta didik dalam menganalisis kebahasaan teks llaporan hasil observasi pada kelas X IPS 1 masih rendah. Dalam pembelajaran guru masih menggunakan metode ceramah, pemberian contoh, dan penugasan. Akhirnya peserta didik merasa kurang tertarik terhadap materi menganalisis kebahasaan teks laporan hasil observasi. Muncullah permasalahan kurangnya keaktifan peserta didik dalam kegiatan pembelajaran pencapaian hasil belajar yang kurang optimal. Hal ini menyebabkan hasil belajar rendah, yakni peserta didik yang tuntas belajar hanya $32 \%$ dengan rata-rata nilai di bawah KKM. Suasana gaduh yang disebabkan peserta didik kurang serius dalam mengikuti pembelajaran. Peserta didik tidak memperhatikan penjelasan guru, kurang merespon pertanyaan yang diberikan guru dalam apersepsi, membuat suasana kurang kondusif, ada yang mengantuk, dan bahkan ada beberapa peserta didik yang berbicara dengan teman sebangku serta motivasi belajar sangat rendah. Dengan demikian kondisi ini perlu ditindaklanjuti untuk materi menganalisis kebahasaan teks laporan hasil observasi agar peserta didik lebih termotivasi melalui metode pembelajaran Group Investigation (GI).

Alasan lainnya, bahwa selama ini metode yang digunakan oleh guru dalam proses pembelajaran masih didominasi dengan metode ceramah (monoton) dan pemberian tugas. Peran guru yang masih mendominasi pelajaran sehingga kurang memberi kesempatan kepada peserta didik untuk lebih banyak mendalami teks laporan hasil observasi . Peserta didik kurang dapat 
memahami unsur-unsur dalam menganalisis kebahasaan teks laporan hasil observasi, atau untuk mengungkapkan kembali teks laporan hasil observasi yang telah didengar atau dibaca. Dari hasil uji pratindakan yang diberikan dengan lima soal uraian yang berkaitan dengan aspek analisis kebahasaan (kata-frasa, afiksasi, kalimat definisi-deskripsi, kalimat simpleks-kompleks) dan membenahi kesalahan bahasa teks laporan hasil observasi hanya 12 peserta didik (33,3\%) yang memperoleh nilai di atas Kriteria Ketuntasan Minimal (KKM), peserta didik yang lainnya 24 anak (66,6 \%) memperoleh nilai di bawah KKM. Nilai rata-rata yang dicapai juga rendah, yaitu 68 masih di bawah KKM yang ditetapkan dalam kurikulum. Berdasarkan hasil tes yang telah dilakukan tersebut diketahui bahwa kemampuan menganalisis kebahasaan teks laporan hasil observasi peserta didik rendah dan perlu ditingkatkan sesuai dengan tujuan dan harapan yang sudah ditetapkan dalam KTSP SMA Negeri 1 Gemolong, yaitu nilai ketuntasan minimal adalah 75 dan nilai ketuntasan klasikal minimal 85\%. Adapun gambaran nilai-nilai peserta didik adalah sebagai berikut:

Tabel 1. Nilai Kondisi Pra Siklus

\begin{tabular}{clc}
\hline No & Uraian & Tes Awal \\
\hline 1 & Nilai terendah & 61 \\
2 & Nilai tertinggi & 87 \\
3 & Nilai rata-rata & 68 \\
4 & Ketuntasan & $65 \%$ \\
\hline
\end{tabular}

Siklus pertama ada dua pertemuan yaitu pertemuan pertama dan kedua, sedang pertemuan ketiga dan keempat untuk siklus II. Pada pertemuan pertama ini peneliti melakukan kegiatan pembelajaran, pengamatan terhadap guru, pengamatan aktifitas terhadap peserta didik, dan pengamatan kompetensi keterampilan. Hasil pengamatan dicatat dalam lembar pengamatan dengan hasil pengamatan terhadap guru sebagai berikut: 1) Guru menyampaikan apersepsi dan tujuan dalam pembelajaran mencapai nilai 55 atau kriteria kurang, 2) guru menjelaskan materi pelajaran mendapat nilai 71 atau kriteria cukup, 3) guru memberi kesempatan kepada peserta didik bertanya hanya mencapai nilai 52 atau kriteria kurang, 4) gurumemotivasi peserta didik yang belum berpartisipasi dalam kelompok, mendapat nilai 62 atau kriteria kurang, 5) guru berkeliling mengontrol kerja masing-masing kelompok, mencapai nilai 76 atau kriteria baik, 6) guru memberi tugas individu kepada peserta didik, mendapat nilai 73 atau kriteria cukup, 7) guru menyimpulkan materi pembelajaran dan refleksi bersama peserta didik, hanya mencapai nilai 60 atau kriteria kurang dikarenakan peserta didik kurang aktif, 8) nilai rata-rata guru dalam pembelajaran sebesar 64,1 atau kriteria kurang.

Sedangkan pengamatan keaktifan peserta didik selama mengikuti pembelajaran sebagai berikut: peserta didik merespon apersepsi guru ada 18 atau 50\%, selebihnya kurang memperhatikan karena masih ngobrol dan ada yang mengganggu teman. Berikutnya peserta didik tenang dan teratur mengikuti pembelajaran, hanya 20 anak atau 55,56\% selebihnya masih belum siap. Peserta didik bertanya materi yang belum jelas, hanya 22 anak atau 61,11\%. Selanjutnya peserta didik aktif terlibat dalam diskusi, hanya 18 anak atau $50 \%$. Peserta didik aktif menanggapi presentasi pekerjaan teman, 24 anak atau 66,67\%. Maka rata-rata keaktifan peserta didik mencapai 20,04 atau 55,56\%. Observasi kompetensi keterampilan terhadap peserta didik dapat diuraikan sebagai beikut: rata-rata kemampuan peserta didik berkomunikasi dengan kelompok sebesar 77 predikat C, rata-rata peserta didik mengerjakan tugas secara mandiri sebesar 68 predikat $\mathrm{D}$, rata-rata kemampuan peserta didik menyampaikan pendapat dalam kelompok sebesar 73 predikat $\mathrm{C}$, rata-rata nilai keterampilan peserta didik sebesar 72,67 predikat C. Berdasarkan hasil pengamatan penelitian pada siklus I, dapat dikemukakan bahwa kualitas pembelajaran menganalisis kebahasaan teks laporan hasil observasi belum mengalami peningkatan yang cukup berarti. Hal ini ditandai oleh beberapa hal berikut : 1) peserta didik yang mampu 
memperoleh nilai di atas batas ketuntasan minimal (KKM) baru 18 orang atau $50 \%, 2$ ) keaktifan peserta didik dalam pembelajaran yang berlangsung belum maksimal. Hal ini terbukti dari rata-rata persentase peserta didik baru mencapai 55,56\%. Peserta didik yang merespon apersepsi $61,1 \%$, yang tenang dan teratur mengikuti pembelajaran $50 \%$, yang bertanya ada $56,25 \%$, yang aktif terlibat diskusi ada 59,38\%, dan yang aktif menanggapi ada 53,33\%.Mereka masih terlihat pasif dan pembicaraan dalam kelompok masih didominasi oleh beberapa orang, 3) peserta didk kurang aktif dalam kerja kelompok, kurang konsentrasi sehingga mereka juga kurang dalam kedisiplinan, kerja sama, dan kurang bertanggung jawab dalam kerja kelompok untuk menyelesaikan tugas yang diberikan, guru sudah mampu mengelolakelas dengan menerapkan metode Group Investigation namun belum maksimal. Rata-rata kinerja guru baru 64,1 Guru belum mampu menciptakan situasi pembelajaran yang mendukung peserta didik untuk aktif, berkonsentrasi, serta termotivasi untuk belajar. Pengawasan guru dalam kelompok masih kurang. Pada pertemuan kedua siklus I, peneliti melakukan perbaikan-perbaikan pada pertemuan pertama. Dari kegiatan pembelajaran pada pertemuan kedua diperoleh data pengamatan terhadap guru. Pengamatan yang dilakukan terhadap kinerja guru dalam pembelajaran pertemuan keduapada siklus I diperoleh hasil: a) Guru melaksanakan pembelajaran dengan menyampaikan apersepsi dan tujuan pembelajaran mencapai nilai 75 atau kriteria cukup. b) Guru menjelaskan materi pelajaran dan memberi contoh yang benar mendapat nilai 80 atau kriteria baik. c) Guru memberi kesempatan kepada peserta didik bertanya tentang kesulitan yang dihadapi hanya mencapai 70 atau kriteria cukup. d) Guru memotivasi peserta didik agar lebih serius dalam pembelajaran hanya mencapai nilai 70 atau kriteria cukup. e) Guru berkeliling mengontrol kerja masing-masing kelompok mencapai nilai 80 atau kriteria baik. f) Guru memberi tugassecara individu mencapai nilai 80 atau kriteria baik. g) Guru menyimpulkam materi dan merefleksi materi pembelajaran hanya mencapai nilai 73 atau kriteria cukup, karena guru mendominasi kegiatan. Nilai rata-rata guru dalam kegiatan pembelajaran 75 atau kriteria cukup. Sedangkan hasil pegamatan keaktifan peserta didik dalam pembelajaran dapat dilihat pada data berikut. Berdasarkan hasil observasi terhadap proses pembelajaran pertemuan kedua pada siklus I diperoleh hasil observasi aktivitas peserta didik dalam pembelajaran sebagai berikut: a) Pesera didik merespon apersepsi guru berjumlah 30 orang atau $80,33 \%$, sedangkan yang lain kurang aktif dan masih ngobrol. b) Peserta didik tenang dan teratur mengikuti pembelajaran berjumlah 28 orang atau $78,78 \%$, selebihnya masih membuka tas, mencari catatan, bahkan ada yang datang terlambat. c) Peserta didik bertanya materi yang belum jelas berjumlah 26 orang atau $72,22 \%$ yang lain masih ragu-ragu. d) Peserta didik aktif terlibat dalam diskusi mencapai 22 orang atau $61,11 \%$, sedangkan yang lain hanya mendengarkan temannya diskusi. e) Peserta didik aktif menanggapi presentasi pekerjaan teman mencapai 22 orang atau $61,11 \%$, sedangkan yang lain hanya memperhatikan teman yang menanggapi. Dengan rata-rata keaktifan peserta didik dalam pembelajaran mencapai 25 orang atau $69,4 \%$. Pengamatan aspek keterampilan peserta didik selama proses pembelajaran yang dilakukan oleh peneliti dengan hasil berikut: a)Rata-rata kemampuan peserta didik berkomunikasi dengan kelompok sebesar 78 atau predikat B. Hal ini disebabkan baik guru maupun peserta didik baru mengalami model pembelajaran seperti tersebut dan guru baru dua kali mengikuti diklat kuriklum 2013 .b)Rata-rata peserta didik mengerjakan tugas secara mandiri sebesar 79 atau B, sehingga guru perlu memperhatikan waktu pemberian tugas rumah. c) Rata-rata kemampuan peserta didik menyampaikan pendapat dalam kelompok sebesar 75 atau predikat $C$, sehingga guru harus lebih memperhatikan pelaksanaan diskusi. d) Rata-rata nilai kemampuan peserta didik 
sebesar 77,33 predikat $\mathrm{B}$, sehingga guru perlu meningkatkan keterampilan peseta didik lebih optimal. Dengan rata-rata nilai kemampuan peserta didik sebesar 77,33 predikat B, sehingga guru perlu meningkatkan keterampilan peserta ddik lebih optimal. Berdasarkan hasil tes dari KD menganalisis kebahasaan teks laporan hasil observasi dapat diketahui bahwa niali terendah 63 , nilai tertinggi 86 , sedangkan ketuntasan mencapai $71,88 \%$, nilai rata-rata kelas sebesar 77,81. Berdasarkan hasil belajar peserta didik terdapat beberapa kelemahan peserta didik selama pembelajaran berlangsung. Adapun kekurangan pada bahan kalimat simpleks dan kalimat kompleks, karena peserta didik tampak kurang serius, malas, dan kurang aktif. Pada pertemuan ketiga dan keempat peneliti melakukan perbaikanperbaikan pada pertemuan kesatu dan kedua. Dari kegiatan pembelajaran pada pertemuan ketiga diperoleh data sebagai berikut. Hasil pengamatan terhadap kinerja guru diperoleh hasil: 1) Guru melaksanakan pembelajaran dengan menyampaikan apersepsi dan tujuan pembelajaran mencapai nilai 80 atau kriteria baik, 2) guru menjelaskan materi pelajaran dan memberi contoh yang benar mendapat nilai 85 atau kriteria baik, 3) guru memberi kesempatan kepada peserta didik bertanya tentang kesulitan yang dihadapi bisa mencapai 80 atau kriteria baik, 4) guru memotivasi peserta didik agar lebih serius dalam pembelajaran sudah mencapai nilai 78 atau kriteria baik, 5) guru berkeliling mengontrol kerja masing-masing kelompok mencapai nilai 85 atau kriteria baik, 6) guru memberi tugas secara individu mencapai nilai 85 atau kriteria baik, 7) guru menyimpulkam materi dan merefleksi materi pembelajaran bisa mencapai nilai 80 atau kriteria baik, 8) nilai ratarataguru dalam kegiatan pembelajaran 81,56 atau kriteria baik. Hasil pengamatan keaktifan peserta didik dalam pembelajaran sebagai berukut: 1) Pesera didik merespon apersepsi guru berjumlah 30 orang atau 80,33\%, sedangkan yang lain kurang aktif dan masih ngobrol, 2) peserta didik tenang dan teratur mengikuti pembelajaran berjumlah 30 orang atau $80,33 \%$, selebihnya masih membuka tas, mencari catatan, bahkan ada yang datang terlambat, 3) peserta didik bertanya materi yang belum jelas berjumlah 30 orang atau $80,33 \%$ yang lain masih ragu-ragu, 4) peserta didik aktif terlibat dalam diskusi mencapai 26 orang atau $72,22 \%$, sedangkan yang lain hanya mendengarkan temannya diskusi, 5) peserta didik aktif menanggapi presentasi pekerjaan teman mencapai 26 orang atau $72,22 \%$, sedangkan yang lain hanya memperhatika teman yang menanggapi, 6) rata-rata keaktifan peserta didik dalam pembelajaran mencapai 28 orang atau $77,86 \%$. Sedangkan hasil pengamatan kompetensi keterampilan peserta didik saat pembelajaran adalah: 1) Rata-rata kemampuan peserta didik berkomunikasi dengan kelompok sebesar 78 predikat $\mathrm{C}, 2$ ) rata-rata peserta didik mengerjakan tugas secara mandiri sebesar 82 predikat $\mathrm{C}, 3$ ) rata-rata kemampuan peserta didik menyampaikan pendapat dalam kelompok sebesar 80 predikat $C, 4$ ) rata-rata nilai keterampilan peserta didik sebesar 80 predikat C. Hasil pengamatan terhadap kinerja guru pada pembelajaran pertemuan keempat siklus 2 bisa dilihat pada tabel sebagai berikut.

Tabel 2. Hasil Observasi terhadap Guru Siklus II

\begin{tabular}{clcc}
\hline No. & \multicolumn{1}{c}{ Aspek yang Diamati } & Skor & Kriteria \\
\hline 1 & Guru menyampaikan apersepsi dan tujuan pembelajaran & 90 & Baik \\
2 & Guru menjelaskan materi pelajaran. & 87 & Baik \\
3 & Guru memberi kesempatan kepada peserta didik untuk bertanya & 90 & Baik \\
4 & Guru memotivasi peserta didik yang belum berpartisipasi dalam & 85 & Baik \\
& dalam kelompok & & \\
5 & Guru berkeliling mengontrol kerja masing-masing kelompok. & 85 & Baik \\
6 & Guru memberi tugas individu & 85 & Baik
\end{tabular}


7 Guru menyimpulkan materi pembelajaran dan refleksi bersama peserta didik.

Rata - rata

$87 \quad$ Baik

$87 \quad$ Sangat Baik

Berdasarkanlembar observasi dan penilaian, diperoleh hasil bahwa kinerja guru pada siklus II pertemuan kedua rata-rata mencapai 87. Dari indikator yang ditentukan diketahui bahwa guru sudah ada kemajuan pada posisi tertentu dalam proses pembelajaran yang dilakukan. Hal ini wajar karena guru mulai terbiasa melaksanakan motode Group Investigation dan pada pertengahan pelajaran guru mulai dapat melaksanakan tugasnya dengan lebih baik. Berdasarkan observasi terhadap keaktifan peserta didik maka diperoleh gambaran pada tabel sebagai berikut.

Tabel 3. Hasil Observasi Keaktifan Peserta Didik Siklus II

\begin{tabular}{llcc}
\hline \multirow{2}{*}{ No } & \multicolumn{1}{c}{ Aspek Pengamatan } & \multicolumn{2}{c}{ Hasil Pengamatan } \\
\cline { 3 - 4 } & & \multicolumn{2}{c}{ Siklus II } \\
\hline 1. & Peserat didik merespon apersepsi guru & $\%$ \\
2. & Peserta didik tenang dan teratur mengikuti pembelajaran & 30 & 86 \\
3. & Peserta didik bertanya materi yang belum jelas & 32 & 89 \\
4. & Peserta didik aktif terlibat dalam diskusi & 30 & 80 \\
5. & Peserta didik aktif menanggapi presentasi pekerjaan teman & 33 & 94 \\
\hline & & 31.2 & 85,8 \\
\hline
\end{tabular}

Observasi aspek keterampilan peserta didik selama proses pembelajaran dilakukan oleh guru sebagai peneliti yang dibantu guru mitrakolaborasi dan dicatat dalam lembar observasi penilaian keterampilan, dapat dilihat tabel berikut :

Tabel 4. Observasi Kompetensi Keterampilan Peserta Didik Siklus II

\begin{tabular}{llcc}
\hline No & \multicolumn{1}{c}{ Aspek Kompetensi Keterampilan } & Nilai & Predikat \\
\hline 1. & Kemampuan peserta didik berkomunikasi dengan kelompok & 86 & $\mathrm{~B}$ \\
2. & Mengerjakan tugas secara mandiri & 82 & $\mathrm{~B}$ \\
3. & Kemampuan peserta didik menyampaian pendapat dalam & 81 & $\mathrm{C}$ \\
$\quad$ Kelompok & 83 & $\mathrm{~B}$ \\
\hline Rata-rata & 83 \\
\hline
\end{tabular}

Berdasarkan hasil tes dari KD menganalisis kebahasaan teks laporan hasil observasi dapat diketahui bahwa nilai terendah 69 , nilai tertinggi 93, sedangkan ketuntasan mencapai $90,63 \%$, nilai rata-rata kelas sebesar 85,03 . Berdasarkan hasil belajar peserta didik terdapat beberapa kelemahan peserta didik selama pembelajaran berlangsung. Adapun kekurangan pada bahan aspek bahasa bagian gaya bahasa, karena peserta didik tampak kurang serius, malas, dan kurang aktif. Untuk lebih jelasnya dapat dilihat tabel berikut

Tabel 5. Hasil Tes Siklus II

\begin{tabular}{lll}
\hline No & Uraian & \multicolumn{1}{c}{ Nilai } \\
\hline 1 & Nilai terendah & 69 \\
2 & Nilai tertinggi & 93 \\
3 & Nilai rata-rata & 85,03 \\
4 & Ketuntasan & $90,63 \%$ \\
\hline
\end{tabular}




\section{Pembahasan}

Berdasarkan hasil survei diperoleh gambaran bahwa keaktifan guru dalam pembelajaran siklus I dalam menganalisis lkebahasaan teks laporan hasil observasi masih rendah. Guru belum menampakkan hasil menggembirakan pada peserta didik. Berikut perbandingan rata-rata keaktifan guru siklus I dengan siklus II.

Tabel 6. Hasil Perbandingan Rata-rata Keaktifan Guru Siklus I dan II

\begin{tabular}{cccc}
\hline No & $\begin{array}{c}\text { Skor Rata-rata Keaktifan } \\
\text { Guru Siklus I }\end{array}$ & $\begin{array}{c}\text { Skor Rata-rata Keaktifan } \\
\text { Guru Siklus II }\end{array}$ & Keterangan \\
\hline 1. & 75 & 87 & Meningkat \\
\hline
\end{tabular}

Dari tabel diatas dapat diperoleh data bahwa hasil observasi guru pada siklus I sebesar 75 dan pada siklus II sebesar 87. Dari data tersebut menunjukkan adanya kenaikan kinerja guru secara dinamis dari siklus I dan siklus II. Guru berusaha memperbaiki kekurangkekurangannya dalam proses pembelajaran dari cara memberi penyampaian tujuan pembelajaran, keaktifan dalam berkelompok. Hasil observasi terhadap kinerja guru dalam menerapkan metode pembelajaran kooperatif tipe Group Investigation dari satu siklus ke siklus-siklus berikutnya, menunjukkan bahwa kinerja guru sudah baik. Pada siklus I guru sudah melaksanakan seluruh langkah-langkah pembelajaran yang telah disusun, namun belum secara maksimal karena masih ada beberapa langkah yang belum dilakukan secara baik. Padasiklus II, kinerja guru semakin baik. Hal tersebut ditunjukkan dengan sudah dilakukannya langkah-langkah pembelajaran secara maksimal.

Berdasarkan hasil survei awal, diperoleh gambaran bahwa keaktifan peserta didik dalam pembelajaran menganalisis kebahasaan teks laoran hasil observasi masih rendah. Peserta didik kurang tertarik dengan teks laporan hasil observasi dan pembelajarannya. Pada pengamatan siklus berikutnya keaktifan peserta didik dalam pembelajaran menganalisis kebahasaan teks laporan hasil observasi mengalami peningkatan. Keterlibatan peserta didik yang diwujudkan dalam kerja sama antar peserta didik dalam kelompok selama proses pembelajaran meningkat. Keaktifan peserta didik dalam pembelajaran dipantau dengan lembar observasi / pengamatan. Berikut merupakan tabel tentang gambaran adanya peningkatan keaktifan belajar peserta didik.

Tabel 7. Hasil Perbandingan Keaktifan Belajar Peserta Didik Siklus I dan Siklus II

\begin{tabular}{|c|c|c|c|c|c|c|}
\hline \multirow[t]{2}{*}{ No. } & \multirow[t]{2}{*}{ Uraian } & \multicolumn{2}{|c|}{ Siklus I } & \multicolumn{2}{|c|}{ Siklus II } & \multirow{2}{*}{ Keterangan } \\
\hline & & $\sum$ & $\%$ & $\sum$ & $\%$ & \\
\hline 1. & Peserta didik merespon apersepsi guru & 30 & 80 & 31 & 86 & Meningkat \\
\hline 2. & $\begin{array}{l}\text { Peserta didik tenang dan teratur } \\
\text { mengikuti pembelajaran }\end{array}$ & 28 & 79 & 30 & 80 & Meningkat \\
\hline 3. & $\begin{array}{l}\text { Peserta didik bertanya materi yang } \\
\text { belum jelas }\end{array}$ & 26 & 72 & 32 & 89 & Meningkat \\
\hline 4. & Peserta didik aktif terlibat dalam diskusi & 22 & 61 & 30 & 80 & Meningkat \\
\hline 5. & $\begin{array}{l}\text { Peserta didik aktif menanggapi presentasi } \\
\text { pekeriaan teman }\end{array}$ & 22 & 61 & 33 & 94 & Meningkat \\
\hline
\end{tabular}


Rata-rata

$25 \quad 69,4 \quad 31,2 \quad 85,8 \quad$ Meningkat

Berdasarkan penggunaan metode Group Investigation tersebut maka kompetensi keterampilan menunjukkan peningkatan. Walaupun peningkatannya tidak begitu signifikan, namun bisa memberikan pembelajaran pada peserta didik saat bersama dalam kelompok masing-masing. Berikut ini merupakan gambaran perbandingan untuk nilai keterampilan.

Tabel 8. Hasil Perbandingan Kompetensi Keterampilan Peserta Didik Siklus I dan Siklus II

\begin{tabular}{ccccc}
\hline No. & Aspek yang Diamat1 & Siklus I & Siklus II & Keterangan \\
\hline 1. & Kemampuan peserta didik berkomunikasi & 78 & 86 & Meningkat \\
& dengan kelompok & 79 & 82 & Meningkat \\
2. & Mengerjakantugas secara mandiri & 75 & 81 & Meningkat \\
3. & Kemampuan peserta didik menyampaikan & 75 & & \\
$\quad$ pendapat dalam kelompok & 77,33 & 83 & Meningkat \\
\hline$\quad$ Rata-rata & & &
\end{tabular}

Dari tabel di atas dapat diperoleh data bahwa rata-rata kompetensi keterampilan peserta ddik pada siklus I sebesar 77,33 dan pada siklus II sebesar 83. Dari data tersebut menunjukkan adanya kenaikan kompetensi keterampilan peserta didik secara dinamis dari siklus I dan siklus II. Peserta ddik berusaha memperbaiki kekurang-kekurangannya dalam proses pembelajaran dari cara memberi tanggapan sesuai dengan tujuan pembelajaran, keaktifan dalam berkelompok. Hasil kompetensi keterampilan peserta didik dalam mengikuti penerapan metode pembelajaran kooperatif tipe Group Investigation dari satu siklus ke siklus-siklus berikutnya, menunjukkan bahwa keterampilan peserta didik dalam diskusi, menyampaikan pendapat, mengerjakan tugas secara mandiri sudah baik. Berikut merupakan gambaran perbandingan dari siklus I ke siklus II yang mengalami suatu peningkatan.

Tabel 9. Perbandingan Nilai Peserta Didik Siklus I dan Siklus I

\begin{tabular}{llccl}
\hline \multirow{2}{*}{ No } & \multirow{2}{*}{ Uraian } & \multicolumn{2}{c}{ Hasil Nilai Tes } & \multirow{2}{*}{ Ket. } \\
\cline { 3 - 4 } & & Siklus I & Siklus II & \\
\hline 1. & Nilai Terendah & 63 & 69 & Meningkat \\
2. & Nilai Tertinggi & 86 & 93 & Meningkat \\
3. & Rata-rata & 77,81 & 85,03 & Meningkat \\
4. & Ketuntasan (\%) & 71,88 & 90,62 & Meningkat \\
\hline
\end{tabular}

Berdasarkan hasil perolehan nilai pada mata pelajaran bahasa Indonesia diketahui bahwa telah terjadi peningkatan hasil belajar dari siklus I rata-rata kelas 77,81 meningkat menjadi 85,03 pada siklus II. Ketuntasan belajar peserta didik meningkat dari 71,88 \% pada siklus I meningkat menjadi 90,62 \% pada siklus II, sehingga perbaikan pembelajaran cukup pada siklus II ini, dan tidak perlu diadakan perbaikan pada siklus III. Pembahasan dalam penelitian merupakan hasil observasi selama penelitian berdasarkan nilai atau hasil perbaikan pembelajaran, pengamatan selama proses perbaikan pembelajaran pada siklus I maupun siklus II berlangsung. Penelitian tindaka kelas ini dilaksanakan untuk kemudian dilakukan refleksi secara keseluruan pada tiap-tiap siklusnya. Pembelajaran yang dilakukan guru dengan sedemikian rupa diharapkan dapat membawa perubahan kearah yang lebih baik. Pembelajaran dengan menggunakan metode pembelajaran kooperatif tipe Group 
Investigation dapat dijadikan salah satu alternatif untuk meningkatkan aktifitas peserta didik serta pemahaman peserta didik terhadap mata pelajaran, sehingga pembelajaran yang berlangsung dapat menjadi lebih baik dan diperoleh secara maksimal. Penggunaan metode kooperatif tipe Group Investigation dapat meningkatkan keaktifan peserta didik dan hasil belajar peserta didik dala bahasa Indonesia kelas X IPS 1 semester 1 Tahun Pelajaran 20192020 SMA Negeri 1 Gemolong. Pada siklus II ini peserta didik diberikan pembelajaran menganalisis kebahasaan teks laporan hasil observasi dengan tetap menerapkan pembelajaqran kooperatif tipe Group Investigation tetapi diiringi dengan beberapa perbaikan. Guru membantu kelompok yang mengalami kesulitan dalam menginvestigasi teks laporan hasil observasi. Peran guru dalam melakukan pengawasan dan pengontrolan lebih diperhatikan. Pada siklus II mengalami peningkatan kualitas proses dan hasil pembelajaran. Nilai yang diperoleh di siklus II meningkat sebanyak 29 anak atau 90,06\% sudah mencapai KKM atau peningkatan sangat besar yaitu sebesar $18,74 \%$ dari siklus I. Peserta didik yang belum tuntas masih 3 anak sehingga pembelajaran menganalisis kebahasaan teks laporan hasil observasi ditujukan pada siklus II.

\section{Simpulan dan Saran}

Berdasarkan hasil analisis, dapat disimpulkan sebagai berikut. Penerapan metode Group Investigation dalam pembelajaran menganalisis kebahasaan teks laporan hasil observasi pada kelas X IPS 1 SMA Negeri 1 Gemolong dapat meningkatkan keaktifan paserta didik dalam KBM. Peserta didik antusias dalam mengikuti pembelajaran karena secara langsung peserta didik dilibatkan. Guru tidak lagi mendominasi pembelajaran. Sebelum guru menerapkan metode Group Investigation dan masih menggunakan metode ceramah, peserta didik kurang tertarik dan kurang antusias sehingga pasif. Kemudian guru menerapkan metode Group Investigation sehingga peserta didk tertarik dan antusias dalam mengikuti KBM. Selain itu, guru juga memilih bahan dan sumber pembelajaran dari beberapa sumber tidak hanya dari buku paket. Media yang digunakan guru tidak hanya papan tulis, kapur, spidol, tetapi juga menggunakan LCD sehingga peserta didik lebih tertarik dalam mengikuti KBM. Melalui penerapan metode Group Investigation ternyata dapat meningkatkan hasil kemampuan menganalisis kebahasaan teks laporan hasil observasi pada peserta didik kelas X IPS 1 SMA Negeri 1 Gemolong. Hal ini dapat ditunjukkan dari hasil nilai kemampuan menganalisis kebahasaan teks laporan hasil observasi peserta didik dari siklus I pertemuan pertama, pertemuan kedua, siklus II pertemuan pertama, dan pertemuan kedua. Selain kenaikan nilai kemampuan tersebut juga terjadi pada kinerja guru dan penilaian proses. Jadi antara proses pembelajaran, kinerja guru, dan nilai kemempuan menganalisis kebahasaan teks laporan hasil observasi saling terkait. Semakin bagus proses pembelajaran dan kinerja guru mengakibatkan nilai yang diraih peserta didik juga bagus. Berdasarkan simpulan diatas maka peneliti mengajukan saran: 1) para guru hendaknya memberi motivasi kepada peserta didik, terutama yang belum aktif dalam pembelajaran ini dan juga memberikan bimbingan yang kemampuannya rendah, harus mengetahui bentuk hambatan yang terjadi selama proses pembelajaran dan mampu mengatasinya, 2) para kepala sekolah membuat kebijakan untuk meningkatkan kompetensi guru melalui kegiatan IHT, workshop, forum ilmiah, dan menyediakan sarana prasarana penunjang pembelajaranyang memadai, memotivasi guru untuk lebih aktif, kreatif, dan inovatif. 


\section{Daftar Rujukan}

Asrori, Mohammad. (2008). Psikologi Pembelajaran. Bandung: CV Wacana Prima.

Depdiknas. (2004). Standar Kompetensi Mata Pelajaran Bahasa dan Sastra Indonesia

Sekolah Menengah Atas. Jakarta: Depdiknas

Dimyati dan Mudjiono. (2002). Belajar dan Pembelajaran: PT Rineka Cipta.

Eggen dan Kauchak. (2005). Methods for Teaching. Jakarta: Gramedia. diunduh tanggal 23

Agustus 2016.

Giyono. (2019). Penerapan Metode Group Investigation untuk Meningkatkan Motivasi dan

Kemampuan Menganalisis Tes Negosiasi Peserta Didik Kelas X MIPA 1 SMA

Negeri 1 Gemolong Tahun Pelajaan 2018/2019. Jurnal Pendidikan, volume 28(1): 116.

Joko Budi Marsono. (2020). Penerapan Model Pembelajaran Kooperatif Tipe Numbered Head Togetther Sebagai Upaya Meningkatkan Prestasi Belajar Ilmu Pengetahuan Sosial. Jurnal Pendidikan, volume 29(1): 77-84.

Kiranawati. (2007). Metode Group Investigation Terhadap Hasil Belajar Siswa.Semarang.

Martinis Yamin. (2007). Kiat Membelajarkan Sastra. Jakarta: Gaung Persada Press.

Mulyasa E. (2007). Kurikulum Tingkat Satuan Pendidikan Sebuah Panduan Praktis. Bandung: PT Remaja Rosdakarya.

Purnyomo. (2011). Upaya Meningkatkan Kemampuan Menulis Cerita Pendek Melalui Pembelajaran Berbasis ICT pada Siswa Kelas IX.8 SMP Negeri 1 Grobogan. Pedagogik Jurnal Pendidikan Dasar dan Menengah, volume 5(2): 59-69.

Sardiman, A.M. (2006). Interaksi dan Motivasi Belajar Mengajar. Jakarta: PT Raja Grafindo Persada.

Sharan. (2005). Cooperative Learning (Inovasi Pengajaran dan Pembelajaran). Jakarta: Ghalia. Diunduh tanggal 23 Agustus 2016.

Sjafrudin Djoko Hidajat Nur. (2011). Optimalisasi Hasil Belajar okok Bahasan Radslag (Meroda) Mata Pelajaran Penjaorkes dengan Model Cooperative Learning Tipe Team Assisted Individualization (TAI). Pedagogik Jurnal Pendidikan Dasar dan Menengah, volume 5(2): 59-69.

Suhartini Arikunto, Suharjono, dan Supardi. (2006). Penelitian Tindakan Kelas. Jakarta: Bumi Aksara.

Suyoto. (2020). Penerapan Model Pembelajaran Kooperatif Tipe STAD Sebagai Upaya untuk Meningkatkan Prestasi Belajar Seni Budaya dan Kesenian pada Siswa Kelas VII B SMP Negeri 3 Weru Tahun Pelajaran 2016/2017. Jurnal Pendidikan, volume 29(1): 85-92.

Suwarto, S. (2017). Pengembangan tes ilmu pengetahuan alam terkomputerisasi. Jurnal Penelitian dan Evaluasi Pendidikan, 21(2), 153-161.

Triman. (2017). Upaya Meningkatkan Hasil Belajar Penjasorkes melalui Permainan Kasbol Siswa Kelas IV SD N Bulakrejo 01 Kecamatan Sukoharjo Kabupaten Sukoharjo Tahun Pelajaran 2016/2017. Jurnal Pendidikan, volume 26(2): 215-224.

W Gulo. (2002). Strategi Belajar Mengajar . Jakarta: Gramedia Widiasarana Indonesia.

Wiwik Hariyati. (2017). Pengaruh Minat Belajar dan Penerapan Metode Teatrikal terhadap Keberhasilan Siswa dalam Pembelajaran Membaca Puisi. Jurnal Pendidikan, volume 26(2):195-204. 